\title{
Dyskusja o pamięci. Polsko-niemieckie spojrzenie w przeszłość
}

[recenzja książki Pamięć polska, pamięć niemiecka. OdXIX do XXI wieku. Wybrane problemy]

\section{Discussion about the memory. A Polish-German look into the past}

[book review Pamięć polska, pamięć niemiecka.

Od XIX do XXI wieku. Wybrane problemy]

\section{Дискуссия о памяти. Польско-немецкий взгляд в прошлое}

[рецензия книги Pamięć polska, pamięć niemiecka.

Od XIX do XXI wieku. Wybrane problemy]

Droblem relacji polsko-niemieckich stanowi jedno z bardziej wielopłaszpomiędzy oboma narodami. Obok kwestii związanych ze współpracą polityczną i ekonomiczną, ważną rolę w stosunkach na linii Berlin-Warszawa odgrywała kwestia kultury pamięci. Tożsamościowy punkt krytyczny, jakim dla obu narodów była II wojna światowa, stał się na wiele dekad determinantem i kreatorem charakteru relacji polsko-niemieckich. Upadek bloku wschodniego i zjednoczenie Niemiec na początku lat 90. ubiegłego wieku stworzyły szanse na wprowadzenie nowej jakości we współpracy polsko-niemieckiej. Nie było to możliwe bez wspólnej refleksji nad fundamentalnymi wydarzeniami z dziejów obu narodów, szczególnie tych, których 
korzenie sięgają początków XIX wieku. Właśnie ten okres stał się bardzo istotny zarówno dla Niemców, jak i Polaków, dając początek zbiorowych mitów społecznych, związanych m.in. z wojnami napoleońskimi. Wydana w 2006 roku publikacja Pamięć polska-pamięć niemiecka stanowi zestawienie wybranych problemów omawianych w ramach organizowanej wspólnie przez Polskie Towarzystwo Historyczne i Związek Historyków i Historyczek Niemiec konferencji, mającej miejsce we wrześniu 2006 roku w Warszawie. Pośród uczestniczących w spotkaniu prelegentów warto wspomnieć o tak rozpoznawalnych nazwiskach, jak prof. dr hab. Krzysztof Mikulski czy Peter Funke, prezes Stowarzyszenia Historyków i Historyczek Niemiec.

Jednym z największych atutów opisywanej publikacji jest jej czytelna struktura. Objętość książki podzielona została na przejrzyste bloki tematyczne porównujące omówienie danego zjawiska przed badaczy niemieckich i polskich. Zaliczają się do nich zarówno zagadnienia szeroko omawiane w dyskursie publicznym, takie jak tożsamościowe podejście do miejsc pamięci i ich rolę w kreowaniu procesów konsolidacji społecznych, jak i te mniej znane, związane choćby z postrzeganiem przez Niemców i Polaków ery napoleońskiej. Duże zróżnicowanie omawianej problematyki powoduje, iż czytelnik nie ma wrażenia, że publikacja stanowi monolit. Wymiana spostrzeżeń, opinii i wyników badań pomiędzy autorami polskimi i niemieckimi dywersyfikuje spojrzenie czytelnika na analizowane problemy.

Część pierwszą opisywanej publikacji stanowi zestawienie przemówień wprowadzających czytelnika w analizowaną problematykę. Interesującym załącznikiem jest również zamieszczone na początku pracy wspólne oświadczenie dotyczące współpracy na tle naukowym pomiędzy środowiskami historyków polskich i niemieckich. Tego typu dokument stanowi dowód na to, iż zagadnienie pamięci stanowi w polsko-niemieckich stosunkach bilateralnych kwestię fundamentalną. Lata 1939-1945 na dekady zdeterminowały wzajemne postrzeganie się obu narodów i generowanie bardzo trwałych społecznie stereotypów. Swoista demitologizacja, przeprowadzona na stronach Pamięci polskiej, pamięci niemieckiej... stanowi o wartości publikacji. Założenie to zostaje rozwinięte w drugiej jej części, na którą składają się referaty wygłoszone przez uczestników konferencji. Pierwszy „blok tematyczny” zawiera omówienie podejścia do miejsc pamięci i zmiany wektorów w niemieckiej polityce historycznej po 1945 roku. Obecnie tekst 
W. Schulze stanowi ciekawy materiał komplementarny np. w odniesieniu do prac A. Wolff-Powęskiej, rozwijając naukowo problem niemieckiego rozliczenia się z okresem nazistowskim. Natomiast tekst R. Trąby, nacechowany mocno metodologiczną narracją, stanowi dla młodych badaczy problematyki wskazówkę dotyczącą doboru metod oraz literatury źródłowej. Dalsze referaty, dotyczące refleksji nad Napoleonem i Wersalu jako „miejscu pamięci”, eksplorują mniej znane polskiemu czytelnikowi fakty z historii obu narodów. Zagadnienie „Zwrotu pamięci”, szeroko omawiane w tekście M. Hettlinga ukazuje fenomen procesu mitologizacji i kreowania nastrojów społecznych w oparciu o symbolikę miejsca. Specyfika niemieckich doświadczeń związanych z Wersalem wydaje się być bardziej złożona niż spojrzenie Polaków, niemniej jednak warto sięgnąć do przedstawionych w zbiorze tekstów, szczególnie w kontekście setnej rocznicy odzyskania przez Polskę niepodległości. Wydaje się, iż kwestie wydarzeń mających miejsce jako konsekwencje I wojny światowej zagoszczą w 2018 rokku na dłużej w polskim dyskursie publicznym.

Dwa ostatnie, zamieszczone w publikacji, teksty dotyczące historii najnowszej również stanowią dopełnienie tematyki obecnej od wielu lat w dyskursie nie tylko społecznym, ale i politycznym w obu państwach. Analiza mechanizmów pamięci zbiorowej, zestawiona $\mathrm{z}$ doświadczeniami funkcjonowania w systemach totalitarnych to ciekawa przestrzeń analityczna, jeszcze nie do końca wyeksploatowana w pracach historyków. Problem lustracji, adaptacji do nowego systemu politycznego oraz transformacji ustrojowej przebiegł równie burzliwie zarówno wśród Niemców, jak i Polaków. Teksty D. Kałwy i M. Sabrowa zachęcają czytelnika do dalszej eksploracji tych zagadnień.

Zebrane w publikacji referaty charakteryzują się dobrze prowadzoną narracją i przejrzystym językiem, co powoduje, że książka nie musi być dedykowana tylko i wyłącznie akademickiemu kręgowi odbiorców. Choć książka nie stanowi komplementarnego omówienia problematyki pamięci w relacjach polsko-niemieckich jest ona doskonałym wprowadzeniem w omawianą problematykę, mając jednocześnie wartość naukową. Być może przybliży ona polskiemu czytelnikowi złożoność doświadczeń historycznych, jakie na przestrzeni ostatnich 300 lat dotknęły narody polski i niemiecki, pozwalając jednocześnie skonfrontować różne, niejednokrotnie całkowicie odmienne interpretacje danych faktów. Otwartość na różnorodność stanowisk to cecha, 
której my, Polacy wciąż musimy się uczyć, a opisywana publikacja jest w tej nauce sporą pomocą.

MGR JAKUB WIESZCZAK

Wydział Nauk Społecznych

Uniwersytet Wrocławski

ul. Koszarowa 3, 51-149 Wrocław

jakub.wieszczak@o2.pl

\section{Bibliografia}

Noga, Z., Schulze, M. (red.). (2009). Pamięć polska, pamięć niemiecka. Od XIX do XXI wieku. Wybrane problemy. Toruń: Wydawnictwo Adam Marszałek. 